\title{
Implementation Of The Preceptorship Model In Midwife Care: Scooping Review
}

\author{
Ana Dyah Aliza ${ }^{*}$, Farida Kartini $^{2}$ \\ ${ }^{1,2}$ University of 'Aisyiyah Yogyakarta. West Ringroad Street No.63, Sleman 55592 , Indonesia \\ 1.anadyahaliza@gmail.com*; ${ }^{2}$ faridakartini@unisayogya.ac.id \\ *corresponding author \\ Submission date: 19 Februari 2021, Receipt date: 17 Maret 2021, Publication date: 1 April 2021
}

\begin{abstract}
The Preceptorship model has different rules in midwifery clinical practice learning for health students. The goal is to find out the students perspective of the preceptorship implementation on midwifery care. This article takes databases from PubMed, Wiley, Google Scholar, and ScienceDirect. The inclusion criteria are primary research, articles published up to 2019 in English and Indonesian. Preceptorship can help preceptors to improve the effectiveness of their teaching and learning environment. There is a new instrument for evaluating preceptorship that has not yet been standardized. The absence of a standard preceptorship instrument causes variations in the application of midwifery preceptorship.
\end{abstract}

Keywords: perspective, preceptorship, student, midwifery

\section{INTRODUCTION}

Based on the Sustainable Development Goals (SDGs), it is stated that the Ministry of Health of the Republic of Indonesia in the 2015-2019 period has a target to reduce the Infant Mortality Rate (IMR) per 1,000 live births from 32 to 24 IMR. Midwives are the health workers who play an important and strategic role in improving maternal and child health. Quality midwifery care is an important support in efforts to improve the welfare and health of mothers and children. According to (Ministry of Health, 2018) in 2018, the total number of midwifery personnel at Public Health Centers throughout Indonesia was 182,655 where the average percentage of the adequacy of midwives in Public Health Centers throughout Indonesia was $83.8 \%$. However, only $57.7 \%$ of cities have met the quality of health services. This is because a large number of midwives in Indonesia is not directly proportional to the quality of services provided. According to (Istri Bartini, 2011), this condition will have a direct impact on the quality of midwifery care services. The service quality of midwives is in the poor category where this condition may increase the risk of medical errors in determining diagnosis, infection prevention, drug administration, and delivery assistance measures.

Clinical practice is an important part of the midwifery education process that aims to implement classroom theory learning and laboratory practice into clinical situations. The midwifery clinical practice system that has been running so far is still reaping many problems so that it has not been able to achieve the expected learning 
objectives (Firoozehchian, et al, 2012) The curriculum has been in place for many years are concerned over experiential education requirements as the number of schools and student enrollment have increased in recent years. Providing clinical placements for a larger number of students has become increasingly challenging for institutions, as most rotations employ the traditional one-to-one student-preceptor model. This increase in demand has led institutions to explore more experiential teaching models.(Mcintyre et al., 2019)

As described by (Myall, Levett-jones, and Lathlean, 2008) that the mentoring process helps students to organize and integrate concepts, prepare strategies to develop a better understanding of themselves as caregivers, and promote commitment to the profession. Snowden (2008) explained that through a constructive clinical learning environment with good guidance, students will find it easier to develop their selfconfidence and competence as well as focus more on student learning needs.

There are several clinical learning methods applied in health education. Preceptorship is a clinical learning process that occurs formally between the preceptor (clinical supervisor) and students. The process aims to provide benefits to students in the form of supervision of guidance by the preceptor in the implementation of clinical guidance so that students will be helped to get their new role in obtaining initial competence in a short time. Cooperation between preceptors and students will improve the quality of preceptorship (Firoozehchian, Taheri and Dadgaran, 2012).

It is important to know how to implement the preceptorship model in perspective midwifery care. There have been several investigations into the application of the preceptorship learning model in midwifery, particularly regarding the function of a teacher or mentoring for students. However, there has been little investigation of how this system functions from a student perspective. (Löfmark et al., 2012). This meant specific opportunities to perform the skills and tasks of their profession in the individual component of orientation. A clinical preceptors' ability to support learners' preparedness is reflected in the literature through best teaching practices.(Beavers et al., 2020)

It is important to know how to implement the preceptorship model in perspective midwifery care. There have been several investigations into the application of the preceptorship learning model in midwifery, in particular regarding the role of teacher or mentor setting for students. However, there has been little investigation of how this system functions from a student perspective.

\section{RESEARCH METHODS}

In this review, a methodology for reviewing literature clustering is adopted as suggested by Arksey and O'malley (2015). The stages of the steps are as follows:

\section{Problem Identification}

Based on the background, the identification of problems that will be used as material for review articles is the implementation of the preceptorship model in midwifery care and the perception of midwifery students who implement the preceptorship learning model.

\section{Research Questions based on Problem Priority}

How is the implementation of the preceptorship model in midwifery care?

\section{Inclusion and Exclusion Framework}

PEOS is used to identify the elements of qualitative research questions so that PEOS is considered appropriate to use (Bettany-Saltikov. 2012) 
International Journal of Health Science and Technology, 2 (3) 2021

Table 1. Framework Research Question

\begin{tabular}{l|l|l|l}
\hline \multicolumn{1}{c|}{ Element } & \multicolumn{1}{|c|}{ Inclusion } & \multicolumn{1}{|c}{ Exclusion } & \multicolumn{1}{c}{ Rationale } \\
\hline Population & $\begin{array}{l}\text { All hierarchy of Midwifery } \\
\text { students; Midwifery students with } \\
\text { other medical students. }\end{array}$ & $\begin{array}{l}\text { Graduate midwifery } \\
\text { Graduate other medical } \\
\text { practitioner }\end{array}$ & $\begin{array}{l}\text { Access preceptorship } \\
\text { for midwifery students }\end{array}$ \\
\hline $\begin{array}{l}\text { Exposure/ } \\
\text { Event }\end{array}$ & $\begin{array}{l}\text { Implementation preceptorship } \\
\text { Clinical placement experience }\end{array}$ & $\begin{array}{l}\text { Access preceptorship } \\
\text { for midwifery students }\end{array}$ \\
\hline Outcomes & Quality of clinical education & & $\begin{array}{l}\text { All types of original } \\
\text { article }\end{array}$ \\
\hline $\begin{array}{l}\text { Study } \\
\text { Design }\end{array}$ & $\begin{array}{l}\text { Qualitative Method, Quantitative } \\
\text { Method, Mix method }\end{array}$ & & \\
\hline
\end{tabular}

\section{Identify Relevant Studies}

Based on the research objectives and questions, the articles used in this study were obtained through a systematic search system. The articles in this study are articles published in the period up to 2019, free full text, human species, and scholarly journals. These were identified using electronic databases from PubMed, Sciencedirect, Wiley, and Google Scholar. The selection of relevant articles is done by determining the inclusion and exclusion criteria as follows.

Table 2. Inclusion and exclusion criteria

\begin{tabular}{|c|c|}
\hline Inclusion Criteria & Exclusion Criteria \\
\hline $\begin{array}{l}\text { a. Articles published in } 2000-2019 \text {, } \\
\text { b. Articles published in English and } \\
\text { Indonesian, } \\
\text { c. In the form of Document/Report/Policy } \\
\text { Draft/Guideline from WHO or formal } \\
\text { education, } \\
\text { d. Articles that discuss the implementation of } \\
\text { preceptorship model in Midwifery care. }\end{array}$ & $\begin{array}{l}\text { a. Opinion article/commentary, article } \\
\text { review, book reviews, } \\
\text { b. Articles which discuss students with } \\
\text { general clinical practice model. }\end{array}$ \\
\hline
\end{tabular}

\section{Prism Flow Chart}

The number of articles found based on article searches that have been carried out is 803 articles. Of the number of articles, many articles were filtered or excluded because the titles did not match the framework, articles in English and Indonesian. In addition, there are 708 articles in the form of reviews. Thus, the number of articles obtained was reduced to 95 articles. A total of 95 articles were filtered again for their abstracts, then 10 articles were obtained. These ten articles will then be extracted and mapped. 


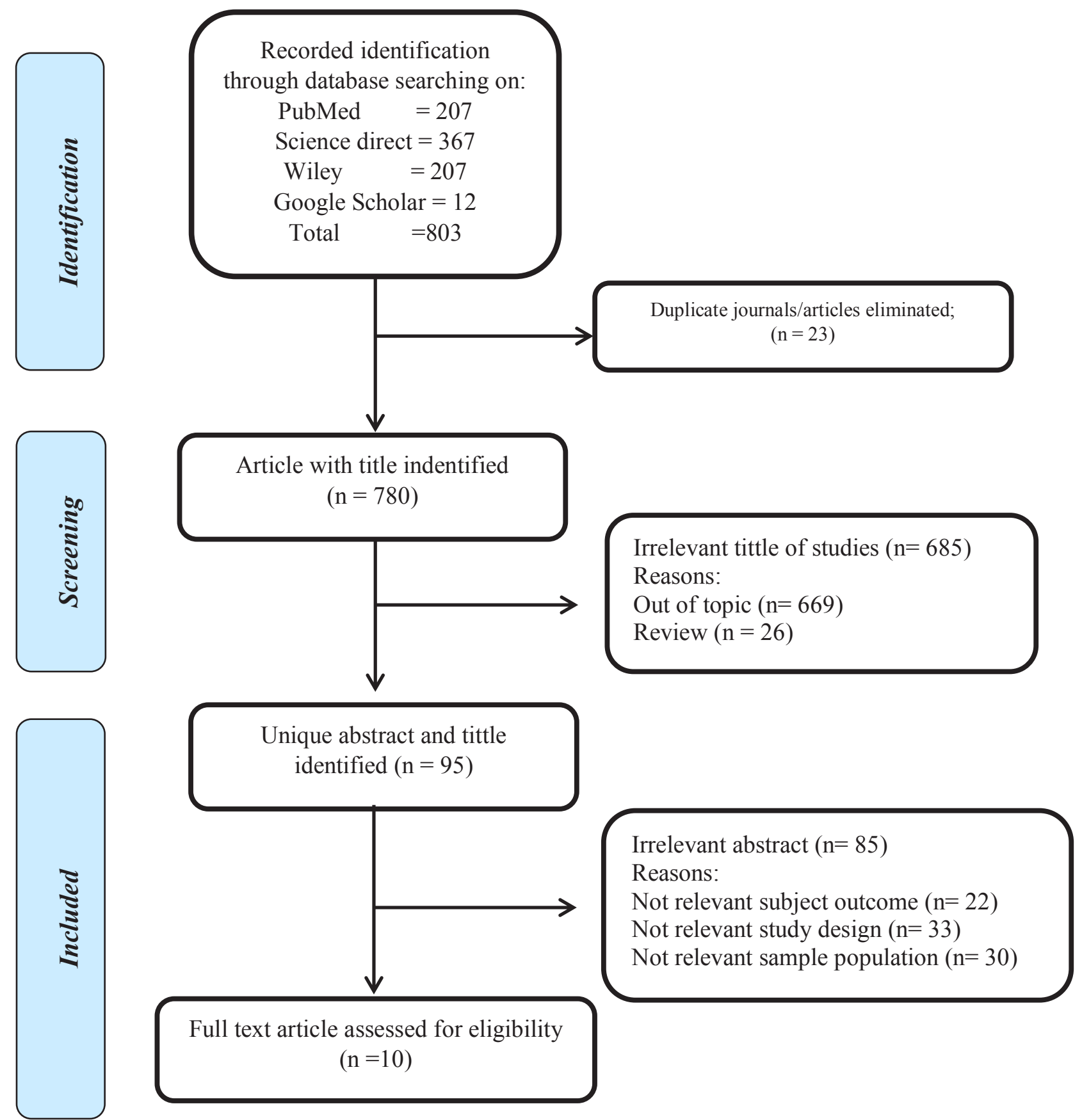

Figure 1. PRISM Flow Diagram

\section{Critical Appraisal}

The tool used for a critical appraisal is the Mixed Methods Appraisal Tool (MMAT). At this stage, 10 articles have been selected and are of good quality. This 
total consists of 4 qualitative study articles, 2 mixed-method study articles, and 3 quantitative study articles.

\section{Literature Mapping}

Articles that have good quality then undergo a data extraction process to classify several points or parts of the article, such as research objectives, research design, sample size, and the results or findings of the research.

Table 3. Literature Mapping

\begin{tabular}{c|l|l}
\hline Topics & \multicolumn{1}{|c|}{ Sub Topics } & \multicolumn{1}{c}{ Articles } \\
\hline \multirow{2}{*}{$\begin{array}{c}\text { Factors which influence } \\
\text { preceptorship } \\
\text { implementation }\end{array}$} & Preceptor rule & $1,2,3,4,8,9$ \\
\cline { 2 - 3 } & Students' skill & 1,9 \\
\cline { 2 - 3 } Preceptorship & Practice place of preceptorship & 1,2 \\
\hline \multirow{2}{*}{\begin{tabular}{l} 
implementation \\
\cline { 2 - 3 }
\end{tabular}} & Preceptorship implementation & $1,3,9,10$ \\
\cline { 2 - 3 } & $\begin{array}{l}\text { Preceptorship inhibition } \\
\text { The difference from conventional }\end{array}$ & $2,6,8$ \\
\cline { 2 - 3 } & Evaluation preceptorship Tool & 8 \\
\cline { 2 - 3 } & The policy in preceptorship & 2 \\
\hline
\end{tabular}

\section{Data Extraction Results}

Tabel 4. Data Extraction

\begin{tabular}{|c|c|c|c|c|c|}
\hline No & $\begin{array}{l}\text { Author } \\
\text { /Year }\end{array}$ & Title & Objective & Research Type & Result \\
\hline 1 & $\begin{array}{l}\text { Safak T. } \\
\text { Gürsoy, et } \\
\text { al } / 2006\end{array}$ & $\begin{array}{l}\text { Evaluation Of An } \\
\text { Educational } \\
\text { Programme In } \\
\text { Ege University, } \\
\text { Turkey: Medical } \\
\text { Student's Home } \\
\text { Visits With } \\
\text { Midwife } \\
\text { Preceptors }\end{array}$ & $\begin{array}{l}\text { To evaluate the role of } \\
\text { the preceptor in } \\
\text { learning } \\
\text { comprehensive } \\
\text { midwifery care for } \\
\text { mothers and families } \\
\text { and to see the } \\
\text { implementation of the } \\
\text { role of the preceptor as } \\
\text { an educator from the } \\
\text { student's perspective. }\end{array}$ & $\begin{array}{l}\text { Mix method } \\
\text { study }\end{array}$ & $\begin{array}{l}\text { Students achieve their } \\
\text { learning goals supported by } \\
\text { the contribution of the } \\
\text { midwife precepts. Midwives } \\
\text { and students carry out good } \\
\text { effective communication. } \\
\text { All participating midwife } \\
\text { precepts reported that pre- } \\
\text { home visit training was } \\
\text { beneficial for students. } \\
\text { Almost all midwives } \\
\text { suggested that home visits } \\
\text { should be longer and } \\
\text { repeated. }\end{array}$ \\
\hline 2 & $\begin{array}{l}\text { Mary Ellen } \\
\text { Doherty / } \\
2015\end{array}$ & $\begin{array}{l}\text { Qualitative } \\
\text { Analysis of The } \\
\text { American College } \\
\text { of Nurse- } \\
\text { Midwives Student } \\
\text { Reports, 2005 To } \\
2014\end{array}$ & $\begin{array}{l}\text { To gain a better } \\
\text { understanding of the } \\
\text { needs of students in the } \\
\text { development of } \\
\text { changes in health } \\
\text { knowledge. }\end{array}$ & $\begin{array}{l}\text { Qualitative } \\
\text { Study }\end{array}$ & $\begin{array}{l}\text { The } 8 \text { emerging themes are } \\
\text { 1) public awareness and } \\
\text { marketing; 2) midwifery } \\
\text { education; 3) funding for } \\
\text { midwifery education; 4) the } \\
\text { issue of receptors; 5) issues } \\
\text { of communication and } \\
\text { professionalism; 6) diversity } \\
\text { and inclusion; 7) transition } \\
\text { to practice, and 8) ACNM } \\
\text { Annual Meeting }\end{array}$ \\
\hline 3 & $\begin{array}{l}\text { Yvonne } \\
\text { Hauck, } \\
\text { et.al / } 2017\end{array}$ & $\begin{array}{l}\text { 'Teaching On The } \\
\text { Run' With } \\
\text { Australian } \\
\text { Midwives In A } \\
\text { Tertiary Maternity } \\
\text { Hospital }\end{array}$ & $\begin{array}{l}\text { To compare the skills } \\
\text { and confidence of } \\
\text { midwives and explore } \\
\text { the perception of } \\
\text { midwifery students on } \\
\text { the support of the } \\
\text { precept during }\end{array}$ & $\begin{array}{l}\text { Mix method } \\
\text { study }\end{array}$ & $\begin{array}{l}\text { Through a systematic } \\
\text { process step, a } \\
\text { comprehensive theme is } \\
\text { formulated, and comes up } \\
\text { with four sub-themes, } \\
\text { namely getting to know each } \\
\text { other; Willingness to share }\end{array}$ \\
\hline
\end{tabular}




\begin{tabular}{|c|c|c|c|c|}
\hline No & $\begin{array}{l}\text { Author } \\
\text { /Year }\end{array}$ & Title & Objective & Research Type \\
\hline & & & implementation. & \\
\hline 4 & $\begin{array}{l}\text { Sharon } \\
\text { Licqurish / } \\
2007\end{array}$ & $\begin{array}{l}\text { Bachelor Of } \\
\text { Midwifery } \\
\text { Students' } \\
\text { Experiences Of } \\
\text { Achieving } \\
\text { Competencies: } \\
\text { The Role Of The } \\
\text { Midwife } \\
\text { Preceptor }\end{array}$ & $\begin{array}{l}\text { To explore the learning } \\
\text { experience of } \\
\text { Midwifery students, } \\
\text { specifically about the } \\
\text { role of midwifery } \\
\text { precepts in learning } \\
\text { and competency } \\
\text { development from a } \\
\text { student perspective. }\end{array}$ & $\begin{array}{l}\text { Qualitative } \\
\text { Study }\end{array}$ \\
\hline
\end{tabular}

knowledge; Leading by example; and Systems that recognize and assess the role of receptors.

A positive teacher-student midwifery relationship is part of successful student learning. Quality receptors can help improve learning outcomes. Hands-on learning emphasizes the most rewarding learning experiences and students seek opportunities to work with midwives who are imbued with a philosophy they admire rather than being synthesized or socialized into the midwifery culture.

\begin{tabular}{|c|c|c|c|c|c|}
\hline 5 & $\begin{array}{l}\text { Semakalen } \\
\text { g H. } \\
\text { Phafoli, et } \\
\text { al / } 2016\end{array}$ & $\begin{array}{l}\text { Student and } \\
\text { preceptor } \\
\text { perceptions of } \\
\text { primary health } \\
\text { care clinical } \\
\text { placements during } \\
\text { pre-service } \\
\text { education: } \\
\text { Qualitative results } \\
\text { from a } \\
\text { quasiexperimental } \\
\text { study }\end{array}$ & $\begin{array}{l}\text { To find out the increase } \\
\text { in competence, self- } \\
\text { confidence, student } \\
\text { satisfaction during } \\
\text { clinical practice at the } \\
\text { first-level health } \\
\text { facilities and to know } \\
\text { the improvement in the } \\
\text { performance of clinical } \\
\text { supervisors as } \\
\text { preceptors. }\end{array}$ & $\begin{array}{l}\text { Qualitative } \\
\text { Study }\end{array}$ & $\begin{array}{l}\text { The clinical practice } \\
\text { supports the competence and } \\
\text { confidence improvement of } \\
\text { nursing and midwifery } \\
\text { students, which will assist } \\
\text { their transition into the } \\
\text { workforce and increase the } \\
\text { likelihood for young } \\
\text { professionals to receive } \\
\text { placements in these areas } \\
\text { after graduation. }\end{array}$ \\
\hline 6 & $\begin{array}{l}\text { Suzanne } \\
\text { M. } \\
\text { Thompson, } \\
\text { et al / } 2018\end{array}$ & $\begin{array}{l}\text { "A powerful } \\
\text { midwifery } \\
\text { vision": Dutch } \\
\text { student midwives' } \\
\text { educational needs } \\
\text { as advocates of } \\
\text { physiological } \\
\text { childbirth }\end{array}$ & $\begin{array}{l}\text { To collect student } \\
\text { opinions about what } \\
\text { they need to be a } \\
\text { physiological birth } \\
\text { attendant. }\end{array}$ & $\begin{array}{l}\text { Qualitative } \\
\text { Study }\end{array}$ & $\begin{array}{l}\text { Students identify dilemmas } \\
\text { associated with supporting } \\
\text { woman-centered care and } \\
\text { promoting physiological } \\
\text { birth. Perceptions in clinical } \\
\text { rules cause difficulties and } \\
\text { lead students to practice } \\
\text { according to the norms of } \\
\text { the midwife's receptors. } \\
\text { Students support the } \\
\text { realization of the philosophy } \\
\text { of midwifery care including } \\
\text { physiological delivery. }\end{array}$ \\
\hline 7 & $\begin{array}{l}\text { Robin } \\
\text { Jordan, } \\
\text { and Cindy } \\
\text { L. Farley / } \\
2008\end{array}$ & $\begin{array}{l}\text { The Confidence } \\
\text { to Practice } \\
\text { Midwifery: } \\
\text { Preceptor } \\
\text { Influence on } \\
\text { Student Self- } \\
\text { Efficacy }\end{array}$ & $\begin{array}{l}\text { to describe students' } \\
\text { experiences of receptor } \\
\text { behavior in therapeutic } \\
\text { and non-interventional } \\
\text { services without any } \\
\text { complications. }\end{array}$ & Quantitative & $\begin{array}{l}\text { Preceptor behavior affects } \\
\text { students' self-confidence to } \\
\text { provide health services. } \\
\text { Students' beliefs about the } \\
\text { value of health for women } \\
\text { are the biggest predictors of } \\
\text { self-efficacy for behavior. }\end{array}$ \\
\hline
\end{tabular}




\begin{tabular}{|c|c|c|c|c|c|}
\hline No & $\begin{array}{l}\text { Author } \\
\text { /Year }\end{array}$ & Title & Objective & Research Type & Result \\
\hline 8 & $\begin{array}{l}\text { Marnie } \\
\text { Griffiths, } \\
\text { et al / } 2019\end{array}$ & $\begin{array}{l}\text { Midwifery } \\
\text { Student } \\
\text { Evaluation of } \\
\text { Practice: The } \\
\text { MidSTEP tool - } \\
\text { Perceptions of } \\
\text { clinical learning } \\
\text { experiences }\end{array}$ & $\begin{array}{l}\text { To develop a tool that } \\
\text { evaluates the } \\
\text { perception of a } \\
\text { student's clinical } \\
\text { learning experience } \\
\text { with the environment } \\
\text { and the impact of the } \\
\text { perceiver in a } \\
\text { professional manner }\end{array}$ & Quantitative & $\begin{array}{l}\text { Overall, students positively } \\
\text { assessed the clinical learning } \\
\text { environment and the ability } \\
\text { of the receptors to foster a } \\
\text { sense of identity as a } \\
\text { midwife. Students are not } \\
\text { satisfied with the teacher's } \\
\text { understanding of academics }\end{array}$ \\
\hline 9 & $\begin{array}{l}\text { Susanti, et } \\
\text { al } 2016\end{array}$ & $\begin{array}{l}\text { Preceptorship } \\
\text { Learning Method } \\
\text { Compared to } \\
\text { Conventional } \\
\text { Towards The } \\
\text { Skill of } \\
\text { Pregnancy } \\
\text { Examination Skill } \\
\text { of Midwifery } \\
\text { Students }\end{array}$ & $\begin{array}{l}\text { to measure the } \\
\text { difference between } \\
\text { preceptorship and } \\
\text { conventional learning } \\
\text { methods on the skills } \\
\text { of midwifery students } \\
\text { in midwifery. }\end{array}$ & $\begin{array}{l}\text { Quantitative } \\
\text { with quasi } \\
\text { experimental } \\
\text { design }\end{array}$ & $\begin{array}{l}\text { The results of this study } \\
\text { indicate that there is a } \\
\text { significant difference in } \\
\text { prenatal care skills between } \\
\text { preceptorship and } \\
\text { conventional methods }\end{array}$ \\
\hline 10 & $\begin{array}{l}\text { Asri } \\
\text { Hidayat, et } \\
\text { al / } 2012\end{array}$ & $\begin{array}{l}\text { Competence } \\
\text { Achievement } \\
\text { Difference of } \\
\text { Labor Care of } \\
\text { Students Between } \\
\text { Preceptorship } \\
\text { Learning Model } \\
\text { of Preceptorship } \\
\text { Model with } \\
\text { Conventional }\end{array}$ & $\begin{array}{l}\text { to determine the } \\
\text { difference in the } \\
\text { achievement of the } \\
\text { second stage of } \\
\text { childbirth care } \\
\text { competence of students } \\
\text { between the } \\
\text { conventional and } \\
\text { preceptorship practice } \\
\text { learning models. }\end{array}$ & $\begin{array}{l}\text { Quantitative } \\
\text { with quasi } \\
\text { experimental } \\
\text { design }\end{array}$ & $\begin{array}{l}\text { Knowledge of second stage } \\
\text { delivery care in the } \\
\text { preceptorship clinical } \\
\text { learning model is higher } \\
\text { than the conventional model, } \\
\text { the second stage delivery } \\
\text { care skills in the } \\
\text { preceptorship clinical } \\
\text { learning model are the } \\
\text { same/no different from the } \\
\text { conventional model. }\end{array}$ \\
\hline
\end{tabular}

\section{RESULT AND DISCUSSION}

\section{The Implementation of Preceptorship}

The preceptorship learning method is a shared responsibility between midwifery education institutions and hospitals. It aims to bridge the gap between theory and practice. Preceptorship is intended to facilitate the transition period of students in increasing competence and confidence (Susanti, Wirakusumah and Garna, 2016) The application of preceptorship includes that rotation during practice only consists of one rotation in one place where the ratio of clinical supervisors to two preceptors is responsible for 5 students in semesters 3-5, more intensive mentoring, skill evaluation with patients. (Hidayat, 2012). The preceptorship model encourages students to adopt a broad public health approach in assessing their defined health needs. This goal can be achieved by having an effective reciprocal relationship between supervisors and students. This is supported by Nursalam (2008) that preceptorship is a popular orientation strategy for nurses and midwives, both students and recent graduates. Preceptor is a nurse who teaches, provides guidance, can inspire colleagues, becomes a role model, and supports individual growth and development (preceptee) for a certain period of time with the specific aim of socializing the preceptee in his new role.

According to (Gursoy, et al, 2008), it is stated that the preceptorship program encourages students to adopt a broad public health approach in assessing public health 
needs. This will increase their awareness of the importance of multi-professional teamwork and comprehensive health care for women and families. The preceptorship program according to Dermawan (2012) consists of three main components, namely: orientation to clinical settings, support and supervision in the clinical field, further development of skills related to clinical settings.

\section{Role of preceptors}

Based on student reports, it was found that they described expressions of gratitude for the contribution of midwife receptors that awakened students with examples of kindness, patience, generosity, and clinical expertise. (Doherty, 2015) Preceptors should focus on their professional role in providing unit-oriented, evidence-based skills-related learning opportunities for the preceptee while in the clinic. (Susanti, Wirakusumah and Garna, 2016) Engaged and committed receptors are critical to the success of midwifery students in a positive clinical practice experience (Griffiths et al., 2019). According to Halfer (2007), the role of the Preceptor must have responsibilities as Role Modeling, Skill Building, Critical Thinking, and Socialization.

In the context of midwifery in Western Australia, Hauck, et al (2017) stated that midwife precepts play a role in guiding and supporting midwifery students during clinical placements and are responsible for ensuring quality patient care. Support by precepts during clinical experiences for students and recent graduates should facilitate the integration of theory into practice to build the knowledge, skills, and attributes essential for professional practice. In Indonesia, according to Windyastuti (2016), preceptors are individuals who have at least 12 years of working experience in the same field or related fields. However, the application of preceptors varies, some of them are less than one year as a preceptor, some are 5 years, and 8 years. The guidance model given on average uses a discussion model.

Not all individuals can have the same criteria as a preceptor. In theory, preceptors must-have competencies such as knowledge, skills, judgment, and attitudes to practice safely and ethically in carrying out their roles in the workplace. This is supported by Gruendemann's research (2015) which explains that preceptors provide a supportive, cohesive and collaborative environment to develop partnerships in learning. Partnerships reduce student anxiety levels and increase productivity through rapid integration of information while ensuring the quality of client care. Preceptor facilitates the learning process in clinical areas. This collaborative approach improves the professional socialization process, thereby reducing the stress level of students. If the preceptor is ready, the burden on students in absorbing information will be reduced. Preceptorship is a structured version of the friendship system. The role of this system is expanded and formally prepared.

\section{Student skills}

It is known that the percentage of competent midwifery student skills for prenatal care before being given the preceptorship learning method is 5.2\%. This percentage increased after being given the preceptorship learning method, which was $63.8 \%$. During the preceptorship process, preceptors need educational strategies to improve skills and think critically in problem-solving. (Susanti, et al, 2016) Students in this process achieve their learning goals, while midwives contribute to their achievement. Scores of eight of the 20 learning objectives improved significantly in the midwife's post-test evaluation. Midwives and students appreciate effective communication with each other. (Gursoy, et al, 2008) 
In the learning objectives, the practice of perceivers needs to provide a physical and social environment to create a realistic and relevant environment. In addition, identification of practice areas that are following competence also needs to be carried out. Another thing that needs to be considered is the suitability of patient capacity with the number of students as well as the availability of receptors from the practice, a practice that gives permission and is willing to accept changes following evidencebased. Thus, the new knowledge and skills acquired by students are realistic and relevant so that they can be applied immediately.

\section{Preceptorship practice place}

Preceptorship in practice areas needs to be evaluated for its implementation because there are still problems with the guidance system, the ratio of supervisors to students comparison, the requirements as supervisors In addition, it is also necessary to improve the quality and competence of preceptorship to produce new graduates who are competent in providing midwifery care. According to (Morton, 2000), it is stated that the process of implementing preceptorship in the room is also different where there is no standard from the hospital so that each preceptor has a different guiding style, some of them provide guidance once a week and are evaluated once a month at the same time. monthly meeting. Preceptors tend to evaluate formality, not checking directly about the correctness of the actions taken in the room.

There were difficulties in arranging home visits for all health students, and access to some households to allow students to gain training experience was denied. (Gursoy, et al, 2008) As a result, the Division of Midwifery Education and the Midwifery Business Network took further actions in the form of 1) continuing to actively seek health graduates and education funds for midwifery education; 2) maintain the health system at regional and national levels to change existing policies that limit and open doors in all facilities to midwifery students; and 3) continuing to work with partner professionals, such as the American Congress of Obstetricians and Gynecologists, (Doherty, 2015).

\section{Preceptorship barriers}

The implementation of preceptorship is a student's transition from theoretical thinking to clinical skills. This process presents challenges to all parties involved. There have been many studies that describe the barriers that may occur during the process of preceptorship, both from the preceptor and the preceptor. There were relatively poor scores on items related to the precept's knowledge of program requirements and understanding of clinical ability at each year level in the Bachelor of Midwifery Program. More effort should be made to help clinicians better understand students' progressive skill development and provide opportunities for increased complexity for senior students. Students identify a lack of opportunities in the clinical setting to raise concerns that also require further consideration. (Griffiths et al., 2019)

Student midwives saw several examples of preceptors or other professionals using EBP to discuss different approaches to maternal care. (Thompson, et al, 2019). Despite strong and ongoing efforts to recruit additional preceptors, there never seems to be a sufficient supply of skilled and willing midwives. Thus, the teacher-student relationship is not without stress due to the demands of the role. (Doherty, 2015) There is difficulty in arranging home visits for all health students, and access to some households to allow students denied training experience. (Gursoy, et al, 2008). Midwife precepts who are described as unhelpful are poor role models, do not allow room for direct practice or take over, are generally unsupportive, and operate in a hierarchical system within clinical institutions. (Licqurish and Seibold, 2008). 
According to Zuhri (2019), the preceptorship model practiced by educational institutions in Indonesia is still not optimal because the number of nurses who have qualifications as supervisors is still minimal, the number of students is not proportional to the number of CIs, the limited time for CIs to provide full guidance on students, and the limitations of facilities and infrastructure in supporting the guidance process in the room.

\section{Differences compared to conventional models}

The skills of midwifery students regarding prenatal care before being given conventional learning methods were $18 \%$ competent, while $40 \%$ were competent after being given conventional learning methods. The conventional learning method is a traditional learning method or also called the lecture method because this method has long been used as an oral communication tool between teachers and students in the learning and learning process (Susanti, Wirakusumah and Garna, 2016). During lectures by listening to lecturers, students will find it difficult to follow or capture the essence of the learning material, so that their activities are limited to making notes whose truth is doubtful.

This is supported by Susanti, et al (2016) who state that the pattern of the active lecturer learning process with passive students is low in effectiveness and cannot develop an active participation process in learning. Preceptoring steps in preceptorship must be following the phase-in learning motor skills and instructional steps. The general strategy of preceptorship is to plan and carry out student learning activities using individual learning contracts accompanied by the preceptor's efforts to allow students to have experience by creating learning opportunities. However, the specific task of the receptors in giving assignments to students did not get significant results on the skills of the preceptorship group statistically.

The mission and values of traditional healthcare systems are to promote quality and safe care for their clients; safe delivery for women and their babies. A positive learning and teaching culture within the maternity hospital promotes this mission and values by providing support to staff and students through effective preceptorship. (Hauck et al., 2017) This program encourages students to adopt a broad public health approach in assessing defined public health needs. At the same time, the midwife's professional knowledge program will make them appreciate their role and function in primary health, and increase their self-esteem. (Gursoy, et al, 2008).

\section{Preceptorship Evaluation Tool}

The description of each evaluation instrument in assessing the quality of the implementation of preceptorship can provide an opportunity to provide a systematic review and explore the clinical learning experiences of students and the place of practice. It is necessary to have a preceptorship evaluation instrument that can cover this.

A tool to evaluate the clinical learning experience of midwifery students is the Midwifery Student Evaluation of Practice (MidSTEP). MidSTEP is a first, both nationally and internationally. Items in MidSTEP reflect students' sense, ability, purpose, resourcefulness, connectedness, and identity as a clustered midwives according to the environment and the impact of receptors on their professional development. (Griffiths, et al, 2019)

Evaluation of clinical performance is a topic of conversation for preceptors. There are no standardized tools or tools for evaluation. Preceptors use a variety of tools. It was found that it was difficult to evaluate the preceptee when it was in a changing place 
(rotation) (Windyastuti, 2016). The process of implementing preceptorship in the room also varies, there is no standard standard from the hospital so that each preceptor has a different guiding style, some guide once a week and are evaluated once a month at monthly meetings, some are given guidance to senior nurses while the evaluation is only request information from the nurse in charge. Preceptors tend to evaluate formality, not checking directly about the correctness of the actions taken in the room. (Morton, 2000)

\section{Policy in perception}

Policies that appear in the preceptorship model are caused by the many obstacles that arise in the implementation of preceptorship in clinical practice, both in primary health services and hospitals. To overcome these obstacles, midwifery students are required to provide their opinions and suggestions to professional organizations so that follow-up actions from the midwife profession arise. This is in line with the opinion of Doherty (2015) Doherty (2015) which states that there is a request from the Board of Directors of ACNM (American College of Nurse-Midwifery) to pay attention to the permanent presence of students and students who provide input and ideas. The voting request raises the rights and website for a more in-depth side-by-side comparison of midwifery education programs. This is an official teacher directory page with indicators to show the availability of skills, and a moderated forum on topics of interest (Doherty, 2015).

\section{CONCLUSION}

Preceptorship is a clinical practice learning strategy that is popular among students. The process of implementing preceptorship in the room is also different where there is no standard from the hospital. Therefore, each preceptor has a different guiding style. Preceptors use a variety of tools in their applications. The problem that arises in preceptorship in many student reports is the difficulty experienced by students in finding their clinical practice area. Professional organizations provide several solutions to problems that arise in preceptorship. One solution is to pay attention to student attendance and facilitate students to provide input and ideas. Efforts are also made to recruit and retain competent receptors.

\section{REFERENCES}

Assistant, D. (2008) 'Evaluation of an educational programme in Ege University, Turkey: Medical student' s home visits with midwife preceptors', pp. 226-237. doi: 10.1016/j.midw.2006.12.003.

Depkes. 2018. Data dan Informasi Profil Kesehatan Indonesia. in https://depkes.go.id/resources/download/pusdatin/profil-kesehatanindonesia/Data-dan-Informasi Profil-Kesehatan-Indonesia-2018.pdf

Dermawan, Deden. 2012. Mentorship dan Perceptorship Dalam Keperawatan. Jurnal Profesi. 1: 1-9.

Beavers, L. et al. (2020) 'Perceptions of preparedness: How hospital-based orientation can enhance the transition from academic to clinical learning.', Canadian Medical Education Journal, 11(4). doi: 10.36834/cmej.61649.

Doherty, M. E. (2015) 'Qualitative Analysis of the American College of NurseMidwives Student Reports, 2005 to 2014', Journal of Midwifery and Women's Health, 60(6), pp. 762-768. doi: 10.1111/jmwh.12349.

Firoozehchian, F., Taheri, Z. and Dadgaran, I. (2012) 'Nursing- in clinical education', 
Procedia - Social and Behavioral Sciences. Elsevier B.V., 47, pp. 1832-1837. doi: 10.1016/j.sbspro.2012.06.908.

Griffiths, M. et al. (2019) 'Midwifery Student Evaluation of Practice: The MidSTEP tool - Perceptions of clinical learning experiences', Women and Birth. Elsevier B.V. doi: 10.1016/j.wombi.2019.09.010.

Gruendemann, Barbara J. 2005. Buku ajar keperawatan perioperatif. Vol. I. Jakarta: EGC

Halfer, D. 2007. A magnetic strategy for new graduate nurses. Nursing economics journal. Vol. 25 (1). Article

Hauck, Y. et al. (2017) "“Teaching on the Run" with Australian midwives in a tertiary maternity hospital', Nurse Education in Practice. Elsevier Ltd, 22, pp. 47-54. doi: 10.1016/j.nepr.2016.11.006.

Istri Bartini, D. (2011) 'Self Reported Analysis of Labor Care by DIII Midwifery Graduate and Medical Error', 27(3), pp. 131-137.

Licqurish, S. and Seibold, C. (2008) 'Bachelor of Midwifery students' experiences of achieving competencies: The role of the midwife preceptor', Midwifery, 24(4), pp. 480-489. doi: 10.1016/j.midw.2007.05.001.

Löfmark, A. et al. (2012) 'Nurse Education in Practice Nursing students ' satisfaction with supervision from preceptors and teachers during clinical practice', Nurse Education in Practice. Elsevier Ltd, 12(3), pp. 164-169. doi: 10.1016/j.nepr.2011.12.005.

Mcintyre, C. et al. (2019) 'An Analysis of Canadian Doctor of Pharmacy Student Experiences in Non- Traditional Student-Preceptor Models', American Journal of Pharmaceutical Education, 83(10). doi: 10.5688/ajpe83107367.

Morton, Cooper A \& Palmer A. 2000.Mentoring, Preceptorship And Clinical supervision (Second Edition). Blackwell sience: Oxford.

Myall, M., Levett-jones, T. and Lathlean, J. (2008) 'Mentorship in contemporary practice: the experiences of nursing students and practice mentors'. doi: 10.1111/j.1365-2702.2007.02233.x.

Nursalam dan Efendi, F. 2008. Pendidikan dalam keperawatan. Jakarta: Salemba Medika

Snowden, S. (2008) 'Mentoring in times of change', British Association of Critical Care Nurses, 13(5).

Susanti, A. I., Wirakusumah, F. and Garna, H. (2016) 'Preceptorship Learning Method Compared to Conventional Method Towards Pregnancy Examination Skill of Midwifery Students', Journal of Health System, 2(1), pp. 34-39. doi: 10.24198/jsk.v2i1.10417.

Thompson, S. M. et al. (2019) "“A powerful midwifery vision": Dutch student midwives' educational needs as advocates of physiological childbirth', Women and Birth. Elsevier B.V., 32(6), pp. e576-e583. doi: 10.1016/j.wombi.2018.12.010.

Windyastuti. 2016. Pelatihan Preceptorship Untuk Meningkatkan Adaptasi Perawat Baru Di Rumah Sakit. Jurnal Ners Lentera. vol 6. no 1

Zuhri, Nur dan Dwiantoro, Luky. 2019. Pengaruh Pelatihan Preceptorship Terhadap Adaptasi Perawat Baru. In: Seminar Nasional Keperawatan dan Call for Paper: Pengembangan Intervensi Keperawatan Berfokus kepada Pasien, 25 November 2017, Gd. Serbaguna Lt. 3 Fakultas Kedokteran Universitas Diponegoro 